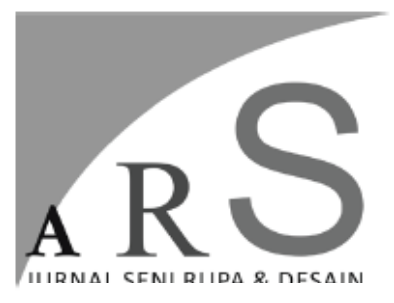

Volume 22 Nomor 3, Desember 2019

\section{STUDI PERUBAHAN DESAIN TATA LETAK SURAT KABAR HARIAN "KOMPAS" TAHUN 1965 - 2015}

\author{
Clara Victoria Padmasari \\ Program Studi Desain Komunikasi Visual, Jurusan Desain \\ Fakultas Seni Rupa Institut Seni Indonesia Yogyakarta
}

\begin{abstract}
ABSTRAK
Penelitian ini akan mencari tahu apa yang telah berubah dalam desain surat kabar KOMPAS dan bagaimana perubahan itu terjadi. KOMPAS adalah raksasa surat kabar yang menerbitkan surat kabar harian. Koran ini sudah lama berdiri di Indonesia. Dari tahun 1965 hingga 2015, KOMPAS telah mengubah desain surat kabar mereka, apakah itu perubahan besar atau evolusi elemen. Ada banyak alasan perubahan tata letak, karena surat kabar diterbitkan setiap hari sehingga menciptakan citra bagi pembaca. Surat kabar saat ini harus bertahan dalam kemajuan teknologi, oleh karena itu ia harus beradaptasi dengan baik dengan perubahan. Penelitian ini menggunakan metode penelitian kualitatif dengan pendekatan historis dan juga pendekatan analisis isi. Hasil dari penelitian ini adalah penjelasan dari evolusi desain Harian KOMPAS dari tahun 1965 hingga 2015 dan juga menjelaskan alasan di balik perubahan dalam desain korannya.
\end{abstract}

Kata kunci: perubahan, koran, tata letak

\begin{abstract}
This research will find out what has changed in KOMPAS newspaper design and how does the changes happened.KOMPAS is a newspaper giant which published daily newspaper. This newspaper has established for a long time in Indonesia. From 1965 until 2015, KOMPAS has changed their newspaper design, whether it's a massive change or an evolution of elements. There are many reasons of changes in layout, because newspaper published everyday thus creating an image to the readers. Newspaper nowadays has to survive in technology advances, therefore it has to adapt well with changes. This research use qualitative research method with bistoric approach and also content analysis approach. The result of this research are explanations of Harian KOMPAS's design evolutions from 1965 until 2015 and also explaining the reasons behind the changes in its newspapers design.
\end{abstract}

Keywords : changes, newspaper, layout 


\section{Pendahuluan}

Usia surat kabar yang hanya sehari menjadikannya salah satu media yang sangat produktif, bahkan di era internet sekarang ini, surat kabar harus mampu bersaing agar dapat bertahan. Salah satu surat kabar yang masih bertahan hingga sekarang yakni surat kabar harian KOMPAS. KOMPAS yang didirikan oleh PK Ojong dan Jakob Oetama telah berdiri sejak tahun 1965. Semenjak didirikan, KOMPAS tidak luput dari adanya redesain atau perubahan tata letak.

Perubahan merupakan fenomena yang terjadi pada lingkup sosial dan kebudayaan. Martono menyebutkan perubahan sosial didasari oleh adanya perubahan nilai, sikap dan pola perilaku yang berlaku pada masyarakat sedangkan perubahan kebudayaan merupakan perubahan yang melingkupi aspek yang luas seperti seni, teknologi, filsafat dan ilmu pengetahuan. (Martono, 2011) Kedua perubahan ini saling berkaitan, bahkan perubahan sosial sendiri merupakan bagian dari perubahan kebudayaan.

Perubahan pada media terjadi karena adanya mediamorfosis, yaitu transformasi media komunikasi, yang biasanya ditimbulkan akibat hubungan timbal balik rumit antara berbagai kebutuhan yang dirasakan, tekanan persaingan dan politik, serta berbagai inovasi sosial dan teknologi. (Fiddler, 2003) Ada tiga prinsip mediamorfosis, yakni :

1. Koevolusi

Evolusi sebuah bentuk tidak dapat dipisahkan dari sebuah sistem. Ketika bentuk berevolusi, bagian dari bentuk itu juga berevolusi.

2. Konvergensi

Mediamorfosis media tidak hanya melibatkan satu faktor saja namun merupakan kombinasi dari sebuah bentuk menjadi bentuk yang baru.

3. Kompleksitas

Adanya perubahan dimunculkan oleh adanya kekacauan atau chaos. Kekacauan tidak berarti sebuah sistem akan mati, namun justru bersifat adaptif dan memunculkan sistem komunikasi yang baru.

Desain tata letak menjadi kunci utama suatu media untuk menyampaikan informasi dengan baik, dan runtut. Selain itu, ia juga menjadi daya jual berita. Maka, dalam tata letak juga perlu ilmu mengenai prinsip desain dan mengenali susunan berita yang mampu menjadi panduan pembaca. Oleh karena itu, pembahasan mengenai tata letak surat kabar tidak bisa lepas dari jurnalistik.

Secara etimologis, kata jurnalistik berasal dari kata journ, yang dalam bahasa Prancis berarti catatan atau laporan harian. Bisa dikatakan pula jurnalistik merupakan pelaporan harian mengenai suatu kegiatan. Menurut Kovach dan Rosentiel, ada sembilan elemen jurnalisme yang harus dipatuhi oleh media, yakni:

Menurut Bill Kovach dan Tom Rosentiel, ada sembilan elemen jurnalisme yaitu (1) Kewajiban pertama jurnalisme adalah pada kebenaran. (2) Loyalitas pertama jurnalisme adalah kepada masyarakat. (3) Intisari jurnalisme adalah disiplin verifikasi. (4) Praktisi jurnalisme harus menjaga independensi terhadap sumber berita. (5) Jurnalisme harus menjadi pemantau kekuasaan. (6) Jurnalisme harus menyediakan forum kritik maupun dukungan masyarakat. (7) Jurnalime harus berupaya keras untuk membuat hal yang penting menarik dan relevan. (8) Jurnalisme harus menyiarkan berita komprehensif dan proporsional. (9) Praktisi jurnalisme harus diperbolehkan mengikuti nurani mereka

Melalui karya ilmiah ini, perlu mencari tahu hal yang melatarbelakangi perubahan desain tata letak surat kabar harian KOMPAS dari awal terbit hingga tahun 2015 juga bagaimana perubahan tersebut diterapkan dalam desainnya. Karya ilmiah ini menggunakan metodologi penelitian kualitatif yang hasilnya berupa data wawancara dan observasi dengan menggunakan pendekatan historis untuk mengungkap peristiwa masa lalu (Sujarweni, 2014) dan pendekatan analisis konten untuk mengetahui penyebab perubahan tata letak surat kabar.

\section{Pembahasan}

Surat kabar harian "KOMPAS" mengalami berbagai macam periode desain. (1) Periode desain yang pertama merupakan awal pertama ia terbit, yakni pada tahun 1965 hingga 
akhir tahun 1970. (2) Pada awal tahun 1971, KOMPAS mengalami perubahan yang pertama dan menjadi periode desain yang kedua. Periode kedua berlangsung hingga tahun 1990, di mana pada saat itu sudah mulai adanya komputerisasi dalam pengerjaan surat kabar. (3) Periode ketiga, yakni pada ulang tahun KOMPAS pada tahun 1990 sudah mulai beralih ke komputer, juga pada periode ini mulai menggunakan software desain. (4) Periode ini berakhir pada tahun 2000 dan berganti wajah lagi bertepatan pada ulang tahun KOMPAS ke-36 tahun. Pada periode ini, KOMPAS menggunakan jasa desain dari Roger Black. Namun desain ini hanya bertahan singkat. (5) Pada tahun 2005, KOMPAS merubah total perwajahannya seperti yang diketahui sekarang.

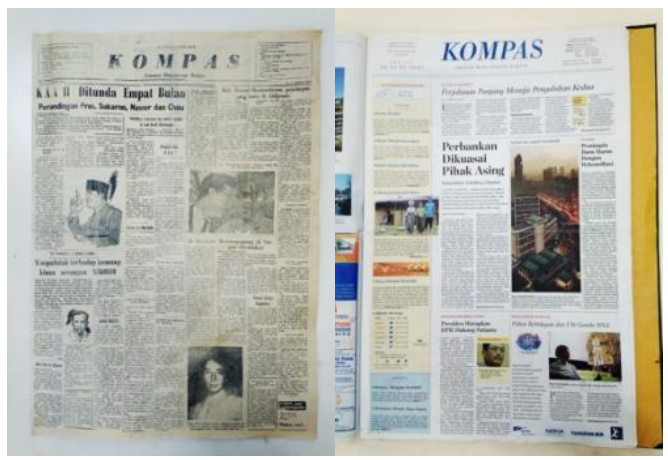

Gambar 1 Perbandingan surat kabar harian KOMPAS tahun 1965 dan tahun 2005 (Sumber : Clara Victoria Padmasari)

Kelima periode desain tersebut dapat dicermati dengan adanya perubahan yang berkaitan dengan adanya perubahan sosial dan perubahan kebudayaan. Perubahan sosial meliputi aspek masyarakat yang membaca surat kabar harian KOMPAS sedangkan perubahan kebudayaan meliputi perubahan pada tubuh keredaksian, teknologi dan iklan pada surat kabar.

Masyarakat yang berubah menghasilkan perubahan juga terhadap surat kabar, karena adanya loyalitas surat kabar terhadap masyarakat. Teknologi pada masyarakat mempengaruhi nilai dan sikap masyarakat. Menurut Harrower, surat kabar modern berkaitan dengan adanya pembaca modern, yakni memiliki gaya hdup yang sibuk, tidak sabaran dan cenderung pemilih. (Harrower, 2013) Hal ini juga tidak lepas dari adanya regenerasi pembaca, yakni generasi $\mathrm{X}$ dan $\mathrm{Y}$ yang lebih mahir dalam teknologi internet.

Pembaca modern lebih senang melihat hal yang sekilas, oleh karena itu KOMPAS memperbesar proporsi elemen visual pada surat kabarnya. Elemen visual tidak hanya berupa fotografi ataupun gambar saja namun adanya variasi warna pada navigasi dan kata kunci membantu pembaca mengindentifikasi persoalan dalam suatu artikel. Navigasi dan kata kunci sebenarnya merupakan kode visual internet yang diterapkan sebagai bentuk pengakraban bentuk internet dan cetak. Hal ini juga menyangkut adanya kewajiban surat kabar agar tetap relevan dengan zamannya.

Keredaksian mengalami koevolusi terlebih dahulu, dimulai dari tren desain surat kabar yang mengecil. Surat kabar yang mengecil memaksa isi surat kabar mengalami koevolusi dengan menulis secara padat (concise). Adanya internet juga mempengaruhi filosofi keredaksian. Prinsip kompleksitas dari internet menghasilkan adanya sebuah bentuk yang lebih adaptif pada desain surat kabar yang cenderung memiliki kode visual yang kompleks namun saling berhubungan (linked). Variasi pada elemen visual disebabkan adanya prinsip kejelasan informasi (visual), mudah dikenal (visible), serta visual thinking.

Visual thinking mengubah isi surat kabar KOMPAS yang tadinya menggunakan banyak teks beralih kepada keseimbangan antara foto dan teks. Visual thinking selain membuat informasi lebih menarik, juga membantu pembaca dalam menangkap inforasi lebih cepat. Prinsip ini akhirnya menghasilkan produk jurnalistik yang baru, yakni infografis. Infografis yang sebelumnya menjadi bagian dari sebuah berita menjadi berita tersendiri. Infografis pun juga merupakan sebuah konvergensi media, yakni adanya hubungan jurnalistik, visual thinking, serta teknologi cetak.

Selain infografis, konvergensi juga terjadi dengan adanya hubungan berita cetak dan berita online dengan adanya dakode dan refer kepada video wawancara. Namun dakode tidak lagi dipakai pada redaksi sehingga refer diandalkan untuk berita lebih lanjut pada artikel tertentu. 


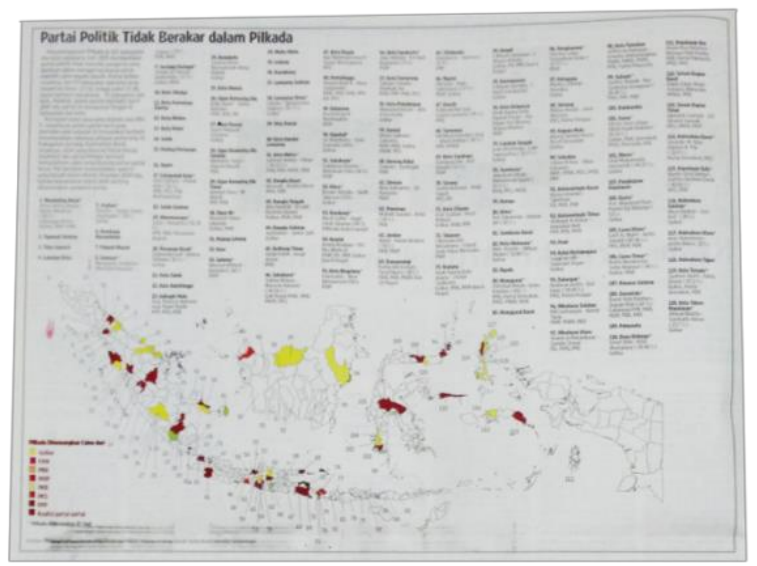

Gambar 2 Infografis pada surat kabar harian KOMPAS tahun 2005

(Sumber : Clara Victoria Padmasari)

Faktor berikutnya, yakni faktor teknologi yang memungkinkan pembaca untuk dapat merasakan apa yang divisualkan oleh fotografer bahkan infografis, dengan adanya reka adegan melalui visual. Reka adegan visual memiliki nilai yang tinggi karena penyampaian berita yang lugas dan jelas. Kelugasan, kejelasan merupakan elemen jurnalistik yang harus dipenuhi oleh media massa. Koevolusi surat kabar terjadi karena adanya bantuan teknologi yang menghasilkan cetakan berwarna sehingga menghasilkan variasi elemen visual dan elemen teks yang menarik.

Hal ini tidak lepas dari adanya perubahan mesin cetak dan sistem komputerisasi yang terjadi pada tubuh redaksi. Pada awalnya redaksi menggunakan mesin Linotype milik PT Kinta dan menghasilkan cetakan yang kurang rapi dengan garis yang putus-putus. Lalu pada periode berikutnya, KOMPAS menggunakan jasa PT Gramedia sejak tahun 1972 dan cetakan yang dihasilkan sudah mulai rapi dan bisa digunakan untuk mencetak warna. Sejak tahun 1990, KOMPAS sudah melakukan komputerisasi dengan menggunakan peranti lunak Quack Express lalu pada 2003 sudah menggunakan GN3, peranti lunak terintergrasi berbasis XML. Adanya komputerisasi tidak luput dari pengurangan karyawan seperti korektor bahasa namun juga memunculkan lapangan kerja baru pada bidang teknologi informasi dan infografis.

Perubahan besar KOMPAS dalam iklan terjadi pada tahun 2005 yang meluncurkan Rubrik Klasika. Klasika sendiri berisi iklan- iklan baris dan iklan display. Namun Klasika cenderung ditinggalkan pembaca, sehingga dibuatlah rubrik baru bernama Intermezzo. Rubrik Intermezzo sendiri berisi permainan seperti sudoku, teka-teki silang, dan komik. Namun bukan berarti rubrik ini bebas iklan, karena iklan pun dapat masuk ke rubrik ini sebagai tips ataupun kontes.

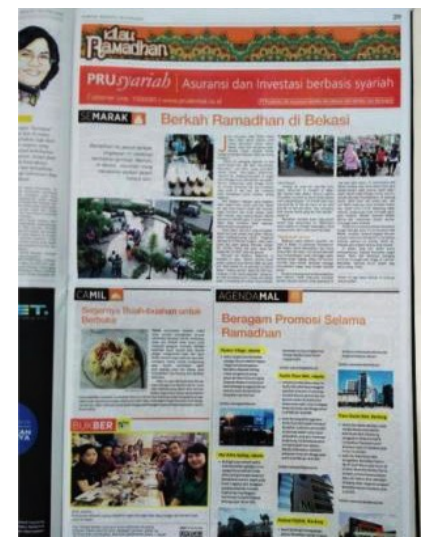

Gambar 3 Iklan advertorial pada surat kabar KOMPAS tahun 2015

(Sumber : Clara Victoria Padmasari)

Iklan pada surat kabar tidak lepas dari adanya komodifikasi ruang dan bentuk. Komodifikasi ruang terlihat dengan adanya ruang iklan yang semakin besar, banyak dan variatif. Sebelumnya, KOMPAS hanya memiliki batasan iklan sebanyak 32\%, kini batasan iklan berjumlah $40 \%$ dari total halaman. Iklan pun tidak lagi diletakkan pada bawah halaman, namun juga bisa satu halaman penuh, bahkan menjadi cover surat kabar. Namun, komodifikasi ruang memiliki batasan, yakni tidak boleh adanya iklan pada Rubrik Opini dan halaman 15 yang berisi sambungan berita. Walaupun memiliki batasan, namun jumlah iklan mempengaruhi adanya penambahan halaman pada surat kabar.

Selain ruang, iklan pun mengalami komodifikasi bentuk. Jurnalisme pada surat kabar tidak lagi hanya berupa informasi yang akurat, namun juga informasi yang disponsori oleh iklan. Informasi tersebut biasanya berisi tips atau keunggulan produk yang bernama advertorial dan informasi mengenai sebuah perayaan yang bernama seremonial. Iklan tidak lagi hanya penawaran, namun juga infomasi seperti halnya jurnalisme, walaupun kebenarannya diragukan. 


\section{Kesimpulan}

Perubahan signifikan KOMPAS terjadi pada tahun 2005, yang pada tahun sebelumnya perubahan hanya berjalan perlahan, tidak banyak berubah. Sebelum tahun 2005, KOMPAS belum berani melakukan perubahan besar untuk menjaga citra surat kabar konservatif. Salah satu alasan KOMPAS berubah adalah regenerasi pembaca, yakni anak-anak muda yang dekat dengan internet.

Setelah mengalami redesain berulang kali, citra KOMPAS sebagai media independen dan konservatif tidak terpampang secara tegas, terutama setelah redesain oleh Mario Garcia. Ciri konservatif KOMPAS kurang tegas dengan banyaknya elemen visual yang mengambil porsi tata letak yang cukup banyak dan menggunakan warna yang variatif. Walaupun memudahkan dan merangkul segala pembaca, namun perlu ada penegasan dari gaya desain yang diterapkan KOMPAS agar secara simbolis terwujud pada citra yang dimiliki.

Untuk melakukan redesain selanjutnya, sebaiknya ada pemikiran lebih matang dalam memunculkan atau menghilangkan elemen hirarki. Pula redesain pun harus dilaksanakan untuk waktu yang panjang juga harus memperhatikan kesinergisan dengan format online, agar tidak menimbulkan kesan kehilangan jati diri serta untuk mengakrabkan bentuk cetak dan bentuk online.

\section{Daftar Pustaka}

Fiddler, R. (2003). Mediamorfosis. Yogyakarta: Bentang Budaya.

Harrower, T. \& J. M. E. (2013). The Newspaper Designer's Handbook. New York: McGrawHill.

Martono, N. (2011). Sosiologi Perubahan Sosial: Perspektif Klasik, Modern, Posmodern dan Poskolonial. Jakarta: Rajagrafindo Persada. Sujarweni, V. W. (2014). Metodologi Penelitian. Yogyakarta: Pustaka Baru. 